\title{
PENERAPAN PEMBELAJARAN MODEL SOLUTION AND CRITIC GROUP UNTUK MENINGKATKAN AKTIVITAS DAN HASIL BELAJAR SISWA KOMPETENSI DASAR MENGINDENTIFIKASI BENTUK PASAR DALAM KEGIATAN EKONOMI MASYARAKAT PADA MATA PELAJARAN IPS KELAS VIII-B MTS AL-IMAN KLATAKAN SITUBONDO SEMESTER GENAP TAHUN PELAJARAN 2015/2016
}

\author{
John Harisantoso \\ Nursalam
}

\begin{abstract}
Abstrak: Berdasarkan hasil observasi di MTs Al-Iman Klatakan Situbondo, penguasaan IPS cenderung masih rendah dan jauh dari yang diharapkan. Tolak ukur keberhasilan mengajar didasarkan pada ketuntasan belajar $85 \%$ untuk ketuntasan belajar secara klasikal belum tercapai. Berdasarkan latar belakang diatas, maka rumusan masalah, meliputi (1) apakah penerapan pembelajaran medel solution and critic group dapat meningkatkan aktivitas siswa pada kompetensi dasar mengidentifikasi bentuk pasar dalam kegiatan ekonomi masyarakat mata pelajaran IPS Kelas VIII-B MTs Al-Iman Klatakan Situbondo pada semester genap tahun pelajaran 2015/2016?, (2) apakah penerapan pembelajaran model solution and critic group dapat meningkatkan hasil belajar siswa pada pompetensi dasar mengidentifikasi bentuk pasar dalam kegiatan ekonomi masyarakat mata pelajaran IPS kelas VIII-B MTs Al-Iman Klatakan Situbondo semester genap tahun pelajaran 2015/2016? Desain penelitian ini adalah PTK, berkolaborasi dengan guru yang dilakukan 2 siklus. Dalam PTK ada 4 tahap yaitu perencanaan, tindakan, observasi dan refleksi. Data primer dengan mengunakan tes ulangan dan observasi dengan checklist, serta data sekunder dengan wawancara.Berdasarkan hasil penelitian, dapat disimpulkan, (1) penerapan pembelajaran model solution and critic group dapat meningkatkan aktivitas belajar mencapai $87 \%$ (2) penerapan pembelajaran model solution and critic group dapat meningkatkan hasil belajar mencapai $89 \%$.
\end{abstract}

Kata Kunci : Penerapan pembelajaran model solution and critic group, aktivitas dan hasil belajar

\begin{abstract}
Based on observation result on MTs Al-Iman Klatakan Situbondo, mastery IPS inclined still low far from supposed. Success measuring rod teaches to based in successfully learn $85 \%$ to successfully learn classically not yet reached. Based on background, so problem formulation as follows: (1 is applications model study solution and critic group increase student activity in competence base identify market form in subject society economi activity IPS class VIII-B MTs AlIman Klatakan Situbondo academic of year 2015/2016?, and (2) is spplications model study solution and critic group increase result learn student in competence base odentify market form in subject society economi activity IPS class VIII-B MTs Al-Iman Klatakan Situbondo academic of year 2015/2016?. Research design was Classroom Action Research that is done 2 cycles. In Classroom Action Research, there 4 stages that is planning, action, observation, and reflection. Primary data by using repetion test, observation with at checklist, and secondary data with interview. Researcher uses target value necessity determine successful as follows: (1) model study applications solution and critic group can increase activity learn to achieve $87 \%$, and (2) model study applications solutiond and critic group can increase result learn to achieve $89 \%$.
\end{abstract}

Keyword: solution and critic group, learning activity and learning outcomes. 


\section{PENDAHULUAN}

Belajar merupakan masalah bagi setiap orang, hampir semua kecakapan, pengetahuan, keterampilan dan sikap manusia dapat terbentuk dan berubah serta berkembang karena belajar, oleh karena itu balajar sengatlah penting dalam kehidupan sehari-hari. Belajar tidak hanya dilakukan secara formal tetapi juga non formal. Salah satu pelajaran yang diterapkan dalam belajar formal adalah ilmu pengetahuan sosial.

Ilmu pengetahuan sosial merupakan materi pelajaran yang diberikan kepada siswa MTs sebagai bekal agar dapat mengembangkan sikap dan kemampuan serta pengetahuan dan keterampilan dasar, selain itu berperan pula sebagai sarana untuk mengetahui ilmu pengetahuan dan teknologi. Sistem pelajaran IPS Perlu ditingkatkan dan disempurnakan sehingga siswa mampu menguasai materi palajaran IPS dengan baik, dengan penguasaan materi IPS diharapkan siswa mempunyai sikap kritis, analitis, logis, cermat serta disiplin. Disamping mampu menerapkannya pada disiplin ilmu lain atau dalam kehidupan sehari-hari. Untuk itu guru diharapkan aktif dan kreatif dalam melaksanakan kegiatan balajar mengajar sehingga siswa mampu menguasai materi IPS dengan baik.

Kegiatan belajar mengajar dapat berhasil sesuai dengan tujuan yang diharapkan bila proses belajar baik, yaitu dipengaruhi mengoptimalkan intelektual peserta didik sistem pengajaran, belajarnya serta efisien efektifitas proses pembelajaran, disamping itu sarana yang lengkap dan prasarana yang memadahi, juga sangat berpengaruh terhadap kelancaran kegiatan belajar mengajar. MTs Al-Iman Klatakan Situbondo merupakan salah satu MTs AlIman Klatakan Situbondo yang siswanya dalam naungan Islam namun tidak menutup kemungkinan siswanya tergolong banyak, benyaknya kelas 2 terdiri dari VIII-A dan VIII-B. Walaupun siswa yang mendaftar MTs Al-Iman Klatakan Situbondo dari tahun ketahun semakin meningkat sampai melampui kapasitas penerimaan, sehingga dalam seleksi hapir separuh dari jumlah pendaftar yang tidak diterima, tetapi kemampuan siswa yang diterima tergolong sedang, ini mengakibatkan proses belajar mengajar kurang optimal. Adapun faktor lain yang menyebabkan rendahnya hasil belajar siswa adalah kurang minat belajar, kurang percaya diri dan takut bertanya bila kurang jelas, sehingga materi pelajaran sulit untuk dikuasai, khususnya pelajaran IPS.

Di MTs Al-Iman Klatakan Situbondo pengusaan IPS cenderung masih rendah jauh dari yang diharapkan. Tolok ukur keberhasilan mengajar didasarkan pada ketuntasan belajar 85\% untuk ketuntasan belajar secara klasikal belum tercapai. Peneliti mengunakan data karakteristik kelah VIII tahun 2015/2016 kompetensi dasar mengidentifikasi bentuk pasar dalam kegiatan ekonomi masyarakat ini pada krikulum 2006 dikelas 2, sekarang kurikulum 2004 masuk materi palajaran kelas VIII. Adapun data karakteristik kelas VIII pada pokok bahasan statistika dan peluang tahun 2003/2004 selain masalahmasalah yang dialami siswa tersebut diatas, kesulitan siswa memahami materi pelajaran IPS karena: 1) Guru hanya menjelaskan saja, 2) Tidak diberi tes perbaikan, 3) Terpaksa untuk mengejar target kurikulum, 4) siswa pasif dalam kelas dan takut untuk menjelaskan dan memberikan kritikan. Oleh karena itu penelitian menitik beratkan pemberdayaan pembelajaran dengan pembelajaran model solution and critic group dalam rangka membangun keberanian bertanya untuk mengatasi kesulitan belajar. Sehingga siswa lebih berminat belajar IPS, lebih percaya diri dan lebih mudah menguasai materi pelajaran IPS. Akibatnya prestasi belajar siswa khususnya pelajaran IPS dapat meningkat.

Pengajaran dengan menggunakan pembelajaran model solution and critic group menjadi pilihan karena mempunyai banyak kelebihan. Misalnya dalam menyelesaikan permasalahan dapat dilakukan secara bersama-sama, sehingga anak dalam kelompok secara aktif terlibat menemukan permasalahan, relatif anak berani bertanya, lebih percaya diri, sehingga lebih mudah menguasai materi pelajaran IPS. Akibatnya prestasi belajar IPS dapat meningkat. 
Dari uraian tersebut peneliti memilih judul penerapan pembelajaran model solution and critic group untuk meningkatkan aktivitas dan hasil belajar siswa kompetensi dasar mengidentifikasi bentuk pasar dalam kegiatan ekonomi masyarakat pada mata pelajaran IPS kelas VIII-B MTs Al-Iman klatakan situbondo semester genap tahun pelajaran 2015/2016.

\section{METODE PENELITIAN}

\section{Setting Penelitian}

Rancangan penelitian yang dipandang sesuai dengan tujuan penelitian adalah rancangan penelitian tindakan kelas (PTK) karena menurut Hobri (2009) penelitian tindakan kelas adalah penelitian atau Kajian secara sistematis dan terencana yang dilakukan oleh peneliti dan praktisi (dalam hal ini guru) untuk memperbaiki pembelajaran dengan jalan mengadakan perbaikan atau perubahan dan membelajaran akibat yang ditimbulkan.

Desain penelitian yang dipakai dalam penelitian ini adalah model skema spiral dan Hopkins (dalam Arikunto, 2006:94) dengan mengunakan empat fase yaitu: perancanaan, tindakan, observasi dan refleksi. Keempat fase tersebut merupakan suatu siklus untuk melaksanakan penelitian tindakan kelas ditunjukkan dengan bagan berikut: (Hopkins dalam Arikunto, 2006:94).

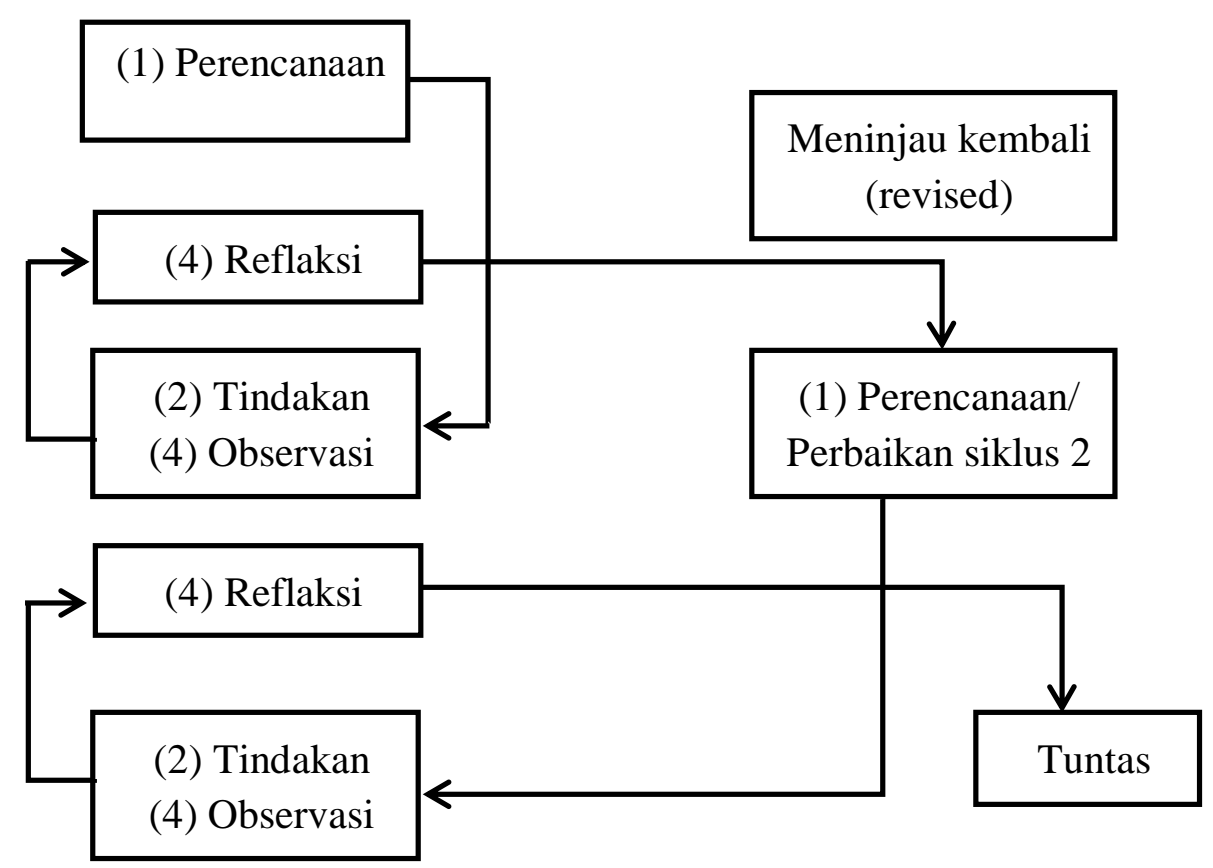

(Hopkins, dalam Arikunto, 2006:94)

\section{Rincian / Prosedur Penelitian}

\section{Perencanaan}

Tahap ini merupakan tahap
merencanakan segala sesuatu ayng
dilakukan dalam penelitian. Kegiatan yang
dilakukan dalam tahap perencanaan ini
adalah sebagai berikut:

1. Menetapkan dan memilih pokok bahasan dengan pelaksanaan dua siklus.
2. Menyusun program silabus dan rendaca pembelajaran untuk masing-masing pokok bahasan yang mengacu pada model solution and critic group.

3. Waktu yang digunakan proses belajar mengajar pada tiap-tiap pertemuan yaitu 2 x 40 menit dengan rincian sebagai berikut:

a. 10 menit digunakan untuk kegiatan pendahuluan; 
b. 60 menit digunakan untuk kegiatan inti;

c. 10 menit digunakan untuk kegiatan reflekksi dan penutup.

4. Mempersiapkan pertanyaan-pertanyaan yang digunakan untuk wawancara dengan guru dan peserta didik mengenai tanggapan terhadap penerapan modelsolution and critic group yang telah diterapkan peneliti dalam prooses belajar mengajar

5. Membuat soal-soal pertanyaan untuk ulangan harian.

6. Membuat lembar observasi yang digunakan peneliti untuk mengamati hasil belajar peserta didik.

\section{Tindakan Pendahuluan}

Hal-hal yang digunakan peneliti pada pelaksanaan tindakan ini adalah peneliti berparan sebagai guru dan peneliti melakukan tindakan berdasarkan pada perencanaan yang telah dibuat. Tindkan yang dilakukan difokuskan pada upaya meningkatkan hasil belajar peserta didik dari rendah menjadi tinggi dengan penerapan model solution and critic group.

\section{Siklus II}

Berdasarkan hasil tindakan pada siklus I, hasil belajar peserta didik kelas VIII-B di MTs Al-Iman Klatakan Situbondo pada mata pelajaran IPS kompetensi dasar mengidentifikasi bentuk pasar dalam kegiatan ekonomi masyarakat telah mengalami peningkatan, tetapi belum mencapai target yang telah ditetapkan paneliti. Peneliti perlu mengkaji dan mencari kekurangan-kekurangan dari siklus I sehingga untuk siklus II indikator hasil belajar peserta didik yang belum meningkat diupayakan untuk lebih diperhatikan. Peneliti berusaha mencari faktor-faktor yang menyebabkan unsur-unsur hasil belajar itu belum mengalamai peningkatan dan berupaya keras untuk memenuhi target yang telah ditetapkan yaitu lebih mengoptimalkan penggunaan penerapan model solution dan critic group.

\section{Refleksi}

Tahap refleksi ini merupakan tahap yang dilakukan peneliti untuk menilai hasil kegiatan belajar peserta didik dari tindakan yang telah dilaksanakan. Peneliti melakukan refleksi dengan cara mengevaluasi hasil belajar peserta didik dengan penerapan model solution and critic group yang telah dilaksanakan. Dengan melakukan refleksi peneliti dapat mengetahui kekurangan kegiatan belajar memgajar yang dilakukan oleh peneliti sehingga depat digunkan untuk menentukan tindakan perbaikan pada siklus berikutnya.

\section{Pengumpulan Data}

Pengumpulan data yang digunakan dalam penelitian ini adalah sebagai berikut:

\section{Observasi}

Metode observasi adalah pengamatan meliputi kegiatan pemusatan perhatian terhadap suatu objek menggunakan alat indera yaitu, pengamatan secara lengsung (Arikunto, 2002:133) observasi pada umumnya digunkan untuk memperoleh data mengenai perilaku individu atau proses kegiatan individu. (Sudjana, 1997:67) observasi dapat dilakukan dengan dua cara:

a. Observasi sistematis, menggunakan pedoman instruman pengamatan.

b. Observasi non sistematis, dilakukan oleh pengamat dengan tidak menggunakan pedoman insrumen pengamatan.

Observasi dalam penelitian ini lakukan dengan cara observasi sistematis dengan pedoman yang disiapkan data yang ingin diperoleh dalam penelitian ini yaitu: pembentukan kelompok dan bantuan individu. Observasi dilaksanakan pada saat pembelajaran di kelas. Pedoman yang digunkan dapatsaat observasi:

1. Panduan observasi, berisikan peraturan atau tata tertib pelaksanaan observasi:

2. Pendahuluan pengamatan, berisikan cara pemberian nilai terhadap hasil pemberian penguatan oleh guru;

3. Lembar pengamatan. 


\section{Wawancara}

Interview adalah suatu cara mengumpulan data dengan jalan tanya jawab sepihak yang dikerjakan dengan sistematika den berlandasan kepala tujuan penelitian. Hal ini seperti pendapat Hadi (1991:193), yaitu: dalam interview selalu ada dua pihak yang masing-masing mempunyai kedudukan sebagai pengajaran informasi (informasi hunter), sedangkan pihak lainnya dalam kedudukan sebagai informasi (information supplier) atau informan. Ada beberapa fungsi interview atau wawancara yaitu:

a. Sebagai model primer, jika satu-satunya alat pengumpulan atau mempunyai kedudukan utama;

b. Sebagai metode pelengkap, jika digunakan hanya untuk mencari informasi-informasi yang tidak dapat diperoleh dengan cara lain;

c. Sebagai metode kreterium, dipergunakan untuk menguji kebenaran dan kemantapan data yang diperoleh dangan cara lain, jadi sebagai alat pertimbangan yang menuntukan.

\section{Tes}

Dalam penelitian ini menggunakan tes uraian yang berjumlah 10 soal. Untuk menuntukan hasil belajar dalam kelas, guru memberikan soal ulangan dengan jumlah soal sebanyak 10 soal tentang kompetensi dasar mengidentifikasi bentuk pasar dalam kegiatan ekonomi mesyarakat.

\section{Analisa Data}

Analisis data yang digunakan dalam penelitian ini adalah analisis deskriptif kualitatif yaitu memaparkan data yang diperoleh hasil pelaksanaan tindakan yang mencangkup proses model solution and critic group dan nilai hasil belajar siswa, selanjutnya dilakukan refleksi untuk mengkaji apa yang telah dihasilkan atau yang belum berhasil dituntaskan dalam tindakan yang telah dilakukan.

Untuk mengetahui peningkatan atau penurunan hasil belajar siswa, peneliti membandingkan skor hasil sebelum dilakukan tindakan dengan setelah dilakukan tindakan. Apabila hasil belajar siswa sebelum dilakukan tindakan lebih tinggi dari hasil belajar siswa setelah adanya tindakan maka tidak ada tingkatan. Sebaliknya apabila hasil belajar siswa balum adanya tindakan lebih rendah dari hasil belajar siswa setelah adanya tindakan maka ada peningkatan. Berdasarkan hasil analisa data, akan ditentukan aktivitas belajar siswa, jika data mengenai observasi yang meliputi: pembentukan kelompok dan bantuan individual. Untuk data yang diperoleh dari hasil wawancara dan dokumentasi akan di deskripsikan untuk mendukung atau melengkapi data primer tersebut. Disamping itu untuk membuktikan adanya peningkatan hasil belajar siswa digunakan standar ketuntasan belajar secara klasikal yang dapat dihitung dengan menggunakan rumus persentase ketuntasan belajar sebagai berikut:

$$
P=\frac{N}{M} \times 100 \%
$$

Keterangan :

$\mathrm{P}$ : Persentase

$\mathrm{N}$ : Skor yang diperoleh peserta didik

M : Skor maksimal

\section{HASIL DAN PEMBAHASAN}

\section{Hasil Pertemuan I}

\begin{tabular}{|c|c|c|c|c|c|}
\hline $\begin{array}{c}\text { Aspek } \\
\text { Indikator }\end{array}$ & \multicolumn{3}{|c|}{ Indikator } & Persen- & $\begin{array}{c}\text { Kate- } \\
\text { tase } \\
\text { gori }\end{array}$ \\
\hline $\begin{array}{c}\text { Mangajukan } \\
\text { Pertanyan }\end{array}$ & 6 & 11 & 2 & $60 \%$ & $\begin{array}{c}\text { Cukup } \\
\text { Aktif }\end{array}$ \\
\hline $\begin{array}{c}\text { Menjawab } \\
\text { Pertanyan }\end{array}$ & 5 & 12 & 2 & $61 \%$ & $\begin{array}{c}\text { Cukup } \\
\text { Aktif }\end{array}$ \\
\hline Diskusi & 6 & 10 & 3 & $61 \%$ & $\begin{array}{c}\text { Cukup } \\
\text { Aktif }\end{array}$ \\
\hline Presentasi & 4 & 15 & 0 & $60 \%$ & $\begin{array}{c}\text { Cukup } \\
\text { Aktif }\end{array}$ \\
\hline \multicolumn{2}{|c|}{$\%$} & & $61 \%$ & $\begin{array}{c}\text { Cukup } \\
\text { Aktif }\end{array}$ \\
\hline
\end{tabular}




\section{Hasil Pertemuan II}

\begin{tabular}{|c|c|c|c|c|c|}
\hline \multirow{2}{*}{$\begin{array}{c}\text { Aspek } \\
\text { Indikator }\end{array}$} & \multicolumn{3}{|c|}{ Indikator } & \multirow{2}{*}{$\begin{array}{l}\text { Persen- } \\
\text { tase }\end{array}$} & \multirow{2}{*}{$\begin{array}{c}\text { Kate- } \\
\text { gori }\end{array}$} \\
\hline & 1 & 2 & 3 & & \\
\hline $\begin{array}{c}\text { Mangajukan } \\
\text { Pertanyan }\end{array}$ & 2 & 15 & 2 & $67 \%$ & $\begin{array}{c}\text { Cukup } \\
\text { Aktif }\end{array}$ \\
\hline $\begin{array}{l}\text { Menjawab } \\
\text { Pertanyan }\end{array}$ & 4 & 13 & 2 & $63 \%$ & $\begin{array}{c}\text { Cukup } \\
\text { Aktif }\end{array}$ \\
\hline Diskusi & 4 & 12 & 3 & $65 \%$ & $\begin{array}{l}\text { Cukup } \\
\text { Aktif }\end{array}$ \\
\hline Presentasi & 2 & 17 & 0 & $63 \%$ & $\begin{array}{c}\text { Cukup } \\
\text { Aktif }\end{array}$ \\
\hline \multicolumn{4}{|c|}{$\%$} & $64 \%$ & $\begin{array}{c}\text { Cukup } \\
\text { Aktif }\end{array}$ \\
\hline
\end{tabular}

\section{Siklus II}

Setelah tindakan II, jumlah siswa yang memperoleh nilai $<70$ berkurang hingga menjadi 2 orang siswa $(11 \%)$ dan yang memperoleh nilai $\geq 70$ sebanyak 17 orang siswa (89\%).

\section{Pembahasan}

Berdasarkan hasil observasi pada siklus I, tampak bahwa tidak ada siswa yang memiliki minat dan perhatian yang rendah terhadap pelajaran. Hal ini karena penelitian dalam menyampaikan materi pelajaran tidak hanya di dalam kelas namun juga di luar kelas agar siswa tidak merasa bosan. Selain itu peneliti juga menggunakan alat bantu mengajar berupa kartu soal dalam menjelaskan materi pelajaran. Penggunaan alat bantu pengjaran tersebut menarik minat dan perhatian siswa terhadap pelajaran.

Pelaksanaan tindakan ke-II peneliti mengadakan penerapan pembelajaran model solution dan critic group dengan pokok bahasan yang sama, yaitu materi pokok pasar yaitu menumbuhkan kemampuan siswa untuk mengumpulkan gagasan soal cerita yang berkaitan dengan pasar. Pada pelaksanaan tindakan ke 2 ini peneliti lebih mempertegas dan lebih memperhatikan bentuk-bentuk siswa yang mempunyai aktivitas belajar yang rendah. Lebih meneankan agar siswa mampu berpikir sendiri atau berfikir mandiri dan mampu menggunakan gagasannya. Dalam pelaksanaan tindakan 2 peneliti laih banyak melakukan tugas dan stimulus belajar dengan menggunkan pola diskusi. Hal ini diharapkan agar siswa mampu untuk bersama-sama berpikir dan menganalisa materi yang diberikan oleh guru dan pada akhirnya siswa mampu menemukan sendiri jawaban, sedangkan guru mengarahkan dan menambah gagasan siswa atau labih memperjelas gagasan tersebut. Dengan ada pembelajaran seperti yang diterapkan, peneliti menemukan temuan bahwa siswa yang mempunyai aktivitas rendah ikut tertarik dan mempunyai keberanian untuk berbicara dan mengungkapkan gagasanya walaupun kadang-kadang jawaban tersebut salah akan tetapi pola peblejaran yang ditetepkan oleh peneliti mampu menumbuhkan semangat balajar yang tinggi juga mampu meningkatkan minat dan perhatian siswa terhadap pelajaran. Pada pelakadanaan tindakan ke II peneliti tindak banyak mengalami kesulitan karena pelaksanaan tindakn ke II penelitian tindak banyak menglami kesulitan karena semua siswa sudah mampu beradaptasi dangan pola pembelajaran model solution and critic group tersebut. Ternyata sebagaian besar siswa $85 \%$ mengatakan proses pengajaran dengan menggunakan pembelajaran model solution and critic group sangat menyenagkan karena banyak hal yang manatang.

Prestasi belajar siswa tidak banyak mengalami perubahan setelah dilaksanakan tindakan II. Pada tindakan I jumlah siswa yang mendapat nilai $<70$ adalah 4 orang, lalu setelah dalaksanakan tindkan II masih terdapat 2 orang siswa yang mendapat nilai $<$ 70. Setelah peneliti mengadakan penyelidikan, ternyata hal tersebut disebabkan olah beberapa faktor. Faktor pertama yaitu siswa yang nilaiya rendah dikarenakan karena memang daya ingat dab kemampuan penyerap pelajaran kurang dalam mengerjakan soal test. Karena aktivitas oleh raga yang dilakukannya pada jam pelajaran sebelumnya, oleh sebab itu siswa tidak bisa konsentrasi penuh dalam mengajaran soal test. Kadua siswa yang nilainya rendah juga disebabkan oleh faktor intelegensi siswa tersebut yang memang rendah. 
Dengan demikian penerapan pembelajaran model solution and critic group dapat diterapkan untuk memupuk atau merangsang dan menjadi dorongan aktivitas belajar siswa karena dengan pola pembelajaran model solution and critic group terbukti bisa meingkatkan aktivitas balajar siswa. Siswa yang mempunyai aktivitas belajar rendah dapat terpancing atau terpicu untuk bisa bersaing dengan teman-temannya yang aktif. Sehingga dapat merangsang daya perpikir siswa. Dalam pembelajaran model solution and critic group ini selain menuntut siswa. Dalam pembelajaran model solution and critic group ini selain menuntut siswa bisa berpikir aktif, berpikir kritis dan dapat menganalisa materi dengan sistematis juga dapat menumbuhkan rasa percaya diri yang tinggi dan siswa mempunyai keberanian berbicara di depan orang lain guna menyampaikan gagasan yang muncul dari ide-idenya. Selain itu pembelajaran model solution and critic group dapat melith siswa terbiasa mengerjakan tugas dengan mendirikan dan mempunyai rasa keberanian yang tinggi.

\section{KESIMPULAN}

Berdasarkan hasil penelitian dan pembelajaran yang telah dilakukan, maka dapat disimpulkan bahwa:

1. Penerapan pembelajaran model solution and critic group dapat meningkatkan aktivitas balajar mencapai $87 \%$ pada kompetensi dasar mengidentifikasi bentuk pasar dalam kegiatan economi masyarakat mata pelajaran IPS kelas VIII-B MTs Al-Iman Klatakan Situbondo semester genap tahun pelajaran 2015/2016.

2. Penerapan pembelajaran model solution and critic group dapat meningkatkan hasil balajar mencapai $89 \%$ kompetensi dasar mengindentifikasi bentuk pasar dalam kegiatan ekonomi masyarakat mata pelajaran IPS Kelas VIII-B MTs Al-Iman Klatakan Situbondo semester genap tahun palajaran 2015/2016.

\section{DAFTAR PUSTAKA}

Arikunto, S. 2002. Metodologi Penelitian. Jakarta: Rineka Cipta.

Arikunto, S. 2006. Prosedur Penelitian Suatu Pendekatan Praktek. Jakarta: Rineka Cipta.

Berenson. 2005. Open Ended Cooperativr Learning. Jakarta: PT Bumi Aksara.

Cholid Narbuko dan Abu Ahmad. 32003. Metodologi Penelitian. Jakarta: PT Bumi Aksara.

Dalyono, M.2001. Psikologi Pendidikan. Jakarta: Rineka Cipta.

Departemen Pendidikan Nasional 2007, Standar Penelitian Pendidikan. Jakarta.

Dewi Ketut Sukardi. 2002. Pengantar Pelaksanaan Program Bimbingan dan Konseling di Sekolah. Jakarta: Rineka Cipta.

Dimyati dan Mudjiono. 2000. Belajar dan Pembelajaran. Jakarta: Rineka Cipta.

Djamarah, S.B. 2000. Rahasia Sukses Belajar. Jakarta : Rineka Cipta

Djamarah, S.B. 2002. Strategi Belajar Mengajar. Jakarta: Rineka Cipta.

Hadi, S. 1991. Metodologi Research Jilid I. Yokyakarta: Andi Offset.

Hakim, Tharsan. 2001. Belajar Secara Efektif. Jakarta: Paspa Swara.

Hasbullah. 2001. Dasar-Dasar Ilmu Pendidikan. Jakarta: PT. Raja Grafindo Persada.

Hobri. 2009. Model-Model Pembelajaran Inovatif. Jember: Pena Salsabila.

Mardalis. 2003. Metodologi Research. Jakarta: Cipta Karya.

Nasution. 2007. Berbagai Pendekatan Dalam Proses Belajar Mengajar. Jakarta: Bumi Aksara.

Nurhadi. 2003. Pembelajaran Berbasis Masalah. Jakarta: Cipta Karya.

Sudjana, N. 1997. Penilaian Hasil Proses Belajar Mengajar. Bandung: Remaja Rosdakarya. 